through more than one edition), nothing would be more easy than to prefix a table of contents, giving the substance of each of the 645 articles.

In conclusion, we earnestly recommend the work to all our scientific friends : it is suitable to every botanical reader, besides being quite indispensable to the Cryptogamic student. Nay more, the zoologist and geologist will find not a little to interest them on the subject of their special studies.

\title{
Synopsis Plantarum Glumacearum. Auctore E. G. SteUdel. Royal 8vo. Stutgard, 1855.
}

This book will be of considerable use to botanists, from its containing full generic and specific characters of the plants known to its author, which are included in the orders Gramineæ, Cyperaceæ, Restiaceæ, Eriocaulaceæ, Xyridaceæ, Desvauxiaceæ, and Juncaceæ. Although Dr. Steudel has apparently done his best to accumulate all that is known concerning the plants of these orders, he has not been altogether successful; for much which has been written in England and also in France seems unknown to him.

It is greatly to be feared that the number of species is multiplied to far greater extent than nature will acknowledge; but in such a work as that before us, this does not seem an unpardonable fault, for each reader is furnished with the means of judging for himself.

Previously to the issue of this book, we were obliged to content ourselves with the very imperfect account of the Gramineæ afforded by Kunth in his 'Enumeratio,' and have therefore much cause for thanking Dr. Steudel for this Synopsis.

\section{Work in the Press.}

Mr. P. H. Gosse has in the press a work on Geology, in which he endeavours to set aside the conclusions of geologists as to the antiquity of the earth, by the application of a principle wholly scientific, which, though hitherto apparently quite overlooked, he believes to be impregnable.

\section{PROCEEDINGS OF LEARNED SOCIETIES.}

ZOOLOGICAL SOCIETY.

January 27, 1857.-Dr. Gray, F.R.S., in the Chair.

On the true NaUtilus umbilicatus of Lister. By Augustus A. Gould, M.D.

In looking over the shells of a dealer in Boston (U. S. A.), I observed three specimens of an umbilicated Nautilus, which struck me 


\section{$2 \mathrm{BHL}$ Biodiversity Heritage Library}

1857. "Synopsis Plantarum Glumacearum. Auctore E. G. Steudel. Royal 8vo. Stutgard, 1855." The Annals and magazine of natural history; zoology, botany, and geology 20, 57-57. https://doi.org/10.1080/00222935709487874.

View This Item Online: https://www.biodiversitylibrary.org/item/19654

DOI: https://doi.org/10.1080/00222935709487874

Permalink: https://www.biodiversitylibrary.org/partpdf/3357

\section{Holding Institution}

Natural History Museum Library, London

\section{Sponsored by}

Natural History Museum Library, London

\section{Copyright \& Reuse}

Copyright Status: Public domain. The BHL considers that this work is no longer under copyright protection.

This document was created from content at the Biodiversity Heritage Library, the world's largest open access digital library for biodiversity literature and archives. Visit BHL at https://www.biodiversitylibrary.org. 